Vol. 1 No. 2 Desember 2021, e-ISSN : 2807-8659 | p-ISSN : 2807-8829

\title{
PENERAPAN MODEL DISCOVERY LEARNING UNTUK MENINGKATKAN MOTIVASI BELAJAR PESERTA DIDIK PADA MATERI SEJARAH KEBUDAYAAN ISLAM
}

\author{
DADANG ABDULAH \\ SMP N 1 Kota Tasikmalaya \\ Email : d42nk.abdullah@yahoo.com
}

\begin{abstract}
ABSTRAK
Penelitian ini bertujuan untuk meningkatkan motivasi dan hasil belajar peserta didik mata pelajaran PAI dengan menggunakan model discovery learning pada pokok bahasan sejarah kebudayaan Islam. Penelitian ini adalah penelitian tindakan kelas yang dilakukan dengan dua siklus. Setiap siklus terdiri dari tahap perencanaan, pelaksanaan, observasi atau pengamatan dan refleksi. Subjek penelitian ini adalah siswa kelas VIII B SMP N 1 Kota Tasikmalaya tahun pelajaran 2018-2019 yang berjumlah 31 orang. Pengumpulan data dalam penelitian ini dilakukan dengan metode observasi untuk melihat kualitas proses pembelajaran, angket/kuesioner untuk mengukur tingkat motivasi belajar siswa. Data yang diperoleh melalui metode observasi dan angket/kuesioner dianalisis dengan teknik deskriptif-kualitatif sedangkan data yang diperoleh melalui tes hasil belajar dianalisis dengan teknik deskriptif-kuantitatif. Hasil penelitian ini menunjukkan peningkatan rata-rata motivasi belajar siswa siklus I ke siklus II sebesar 7\%. Kendala yang dihadapi dalam penerapan model discovery learning yaitu siswa belum terbiasa dengan penerapan model discovery learning yang meliputi Stimulation (stimulasi/pemberian rangsangan), problem statement (pernyataan/identifikasi masalah), data collection (pengumpulan data), data processing ( pengolahan data), verification (pentahkikan/ pembuktian), dan generalization (menarik kesimpulan/ generalisasi) sehingga menjadi tantangan tersendiri bagi guru untuk menyederhanakan pelaksanaannya sehingga siswa dapat mengikuti proses pembelajaran dengan baik.

Kata Kunci : Discovery Learning, Stimulstion, Problem Steatment, Data Collection, Data Processing, Verification, Generalization, Motivasi Belajar,
\end{abstract}

\begin{abstract}
The research aims to improve students learning motivaton and achievement VIII B SMPN 1 Tasikmalaya in PAI Subject through allpaying discovery learning with topic "sejarah dakwah islam". The research is an action research conducted with two cycles. Each cycle consist of flanning, acting, observing and reflecting. The subject of this research is students of VIII B SMP N 1 Tasikmalaya periode 2018-2019 amount 31 students. In this research, the data collection is conducted with observation to find the quality of he learning process, quesionair to mesure the level of students learnin motivation and acchievement. The data was got through obervation and quesionair is analysed with qualitative-descriptive technique, mean while the data was got through learning achievement test is analysed with quantitative-descriptive technique. The research result show the improvement of students learning motivation from cycle I to cycle II in the amount of $7 \%$. Then, the students learning achievement show the improvement from cycle I to cycle II in the amount $4 \%$. The improvement of classical completeness from cycle I to cycle II in the amount of $35 \%$. The constraint in applying discovery learning is the students are unusual with applaying discovery learning involving simulation, problem statement, data collection, data processing, verification and generaltion, so that it will be chellenge for the teacher to simplify the implementation, so that the student can follow the learnin process well.
\end{abstract}

Keyword : Discovery Learning, Stimulstion, Problem Steatment, Data Collection, Data Processing, Verification, Generalization, learning motivation. 


\section{PENDAHULUAN}

Menurut Ahmad Tafsir (2004) dalam pengertian yang luas, pendidikan ialah pengembangan pribadi dalam semua aspeknya, dengan penjelasan bahwa yang dimaksud pengembangan pribadi ialah yang mencakup pendidikan oleh diri sendiri, pendidikan oleh lingkungan, dan pendidikan oleh orang lain (guru). Seluruh aspek mencakup jasmani, akal, dan hati.

Tantangan yang dihadapi dalam Pendidikan Agama Islam sebagai sebuah mata pelajaran adalah bagaimana mengimplementasikan PAI bukan hanya mengajarkan pengetahuan tentang agama, akan tetapi bagaimana mengarahkan peserta didik agar meimiliki kualitas iman, takwa dan akhlak mulia. Dengan demikian pembelajaran PAI akan membentuk kepribadian peserta didik yang memiliki keimanan dan ketakwaan yang kuat dalam kehidupannya dan dihiasi dengan akhlak mulia dimanapun mereka berada.

Ruang lingkup pendidikan agama islam tingkat SMP meliputi keserasian antara hubungan manusia dengan Allah SWT, dengan sesama manusia dan dengan alam serta lingkungan. Adapun ruang lingkup bahan pelajaran pendidikan agama islam di SMP terfokus pada aspek-aspek : 1) Keimanan, 2) Alqur'an/hadits, 3) Akhlak, 4) Fiqih/ibadah dan 5) Tarikh.

Khusus pada ruang lingkup PAI tarikh atau sejarah kebudayaan islam, peneliti sering kali mengalami hambatan. Hambatan itu berupa kesulitan dalam membangkitkan motivasi belajar peserta didik. Peserta didik kebanyakan menunjukkan sikap bosan terhadap materi pelajaran tarikh. Hal ini mungkin disebabkan karakteristik materi tarikh/sejarah itu banyak berhubungan dengan hapalan tahun dimana peristiwa dalam sejarah itu terjadi dan lainnya. Sebab lainnya adalah karena model pembelajaran yang kurang memberikan motivasi kepada peserta didik sehingga mereka tidak tertantang untuk mengikuti proses KBM.

Dalam kurikulum 2013, proses pembelajaran pada satuan pendidikan diselenggarakan secara interakftif, inspiratif, menyenangkan, menantang, memotivasi peserta didik untuk berpartisipasi aktif, serta memberikan ruang yang cukup bagi prakarsa, kreativitas dan kemandirian sesuai dengan bakat, minat dan perkembangan fisik serta psikologis peserta didik.

Ahmad Tafsir, dkk. (2013) menjelaskan bahwa pendekatan pembelajaran yang sesuai dengan prinsip-prinsip pembelajaran tersebut adalah pendekatan ilmiah (scientific). Dalam pendekatan atau proses kerja yang memenuhi kriteria ilmiah, para ilmuwan lebih mengedepankan pelajaran induktif (inductive reasoning) ketimbang penalaran deduktif (deductive reasoning). Untuk memperkuat pendekatan ilmiah dalam kegiatan pembelajaran perlu diterapkan metode pembelajaran berbasis penyingkapan/penelitian (discovery/inquiry learning). Metode penyingkapan/penelitian tergolong dalam teori pembelajaran kontemporer konstruktivisme.

Dengan penggunaan model discovery learning diharapakan akan meningkatkan motivasi belajar peserta didik. Motivasi belajar yang tinggi menggambarkan keberhasilan proses belajar yang pada akhirnya akan meningkatkan hasil belajar yang holistik (utuh) dan berkarakter, yaitu mengembangkan aspek fisik, emosi, sosial, kreativitas, spiritual dan intelektual peserta didik secara optimal serta terbentuknya manusia yang lifelong learnes (pembelajar sejati).

\section{METODE PENELITIAN}

Metode penelitian yang digunakan dalam PTK ini adalah metode deskriptif, yaitu metode penelitian yang berusaha menggambarkan kegiatan penelitian yang dilakukan pada objek tertentu secara jelas dan sistematis. Penelitian deskriptif ini juga berusaha menggambarkan secara jelas dan sekuensial terhadap pertanyaan penelitian yang telah ditentukan sebelum peneliti terjun ke lapangan dan tidak menggunakan hipotesis sebagai petunjuk arah dalam penelitian (Sukardi, 2007).

Pola pelaksanaan PTK ini disebut pola kolaborasi, karena PTK dilakukan secara berpasangan antara pihak yang melakukan tindakan dan pihak yang mengamati proses jalannya 
tindakan. "...cara ini dikatakan ideal karena adanya upaya untuk mengurangi unsur objektivitas pengamat serta mutu kecermatan amatan yang dilakukan" (Arikunto, 2007 : 17).

Dalam pelaksanaan PTK ini peneliti bekerja sama dengan rekan guru PAI lain untuk bertindak sebagai observer. Kegiatan pembelajaran dilaksanakan seperti biasanya, peserta didik dibiarkan melakukan aktifitas sesuai kegiatan kesehariannya seolah-olah tidak ada penelitian.

Model PTK yang digunakan dalam penelitian ini adalah model yang dikembangkan oleh Kemmis dan Mc. Taggart. Empat tahapan secara garis besar yang harus dilakukan dalam PTK, yaitu: (1) perencanaan, (2) pelaksanaan, (3) pengamatan, (4) refleksi (Suharsimi Arikunto, 2007 :16).

Sebagai subjek dalam penelitian ini adalah peserta didik SMP N 1 Tasikmalaya kelas VIII B tahun pelajaran 2018/2019 dengan jumlah peserta didik sebanyak 31 peserta didik. Terdiri dari 16 peserta didik laki-laki dan 15 peserta didik perempuan.

Metode pengumpulan data pada peneitian ini meliputi : Observasi kelas dengan metode tersturktur digunakan untuk mengamati aktifitas guru dan peserta didik dan kuesioner digunakan untuk mengukur tingkat motivasi belajar peserta didik.

\section{HASIL DAN PEMBAHASAN \\ Siklus I}

Pada pertemuan awal sebelum dilaksanakan tindakan, guru mengadakan pretest untuk mengukur tingkat motivasi belajar siswa pada materi sejarah kebudayaan Islam. Dari hasil pengukuran diperoleh nilai 52. Artinya cukup baik. Langkah selanjutnya adalah tindakan penerapan pembelajaran dengan menggunakan model Discovery Leaning. Penelitian ini dilaksanakan mulai tanggal 28 April 2018 sampai dengan 26 Mei 2018 dengan dua siklus. Satu siklus terdiri dari dua kali pertemuan. Pertemuan pertama digunakan untuk KBM dan pertemuan ke dua digunakan untuk penilaian hasil belajar dan pengukuran motivasi belajar peserta didik. Lingkup materinya adalah pada materi sejarah pertumbuhan ilmu pengetahuan masa Nabi muhammad SAW., masa Khulafaurrosyidin, masa masa Bani Umayyah dan masa Bani Abbasiyah. Pembelajaran dengan model Discovery Learning dilaksanakan dengan lima fase, yaitu Stimulation (pemberian rangsangan), Problem Statement (pernyataan/identifikasi masalah), data Collection (pengumpulan data), Data Processing (pengolahan data), Verification (pentahkikan/pembuktian), dan Generalization (Yamin, 2008).

Pelaksanaan pembelajaran siklus I pada tatap muka pertama dengan model discovery learning membahas tentang sejarah pertumbuhan ilmu pengetahuan dalam Islam dengan kompetensi dasar menceritakan sejarah pertumbuhan ilmu pengetahuan Islam sampai masa Abbasiyyah. Tatap muka pertama dilaksanakan pada hari senin tanggal 28 April 2018 jam pelajaran ke $3-4$ pukul 10.00 - 11.30 WIB. Setelah mengucapkan salam dan tegur sapa, guru mengecek kehadiran peserta didik, kemudian memotivasi peserta didik mengenai pentingnya ilmu pengetahuan. Selanjutnya peserta didik menjawab pertanyaan apersepsi dan menyimak tujuan pembelajaran yang harus dicapai pada pertemuan tersebut dan system penilaiannya serta menerima penjelasan tentang model discovery learning.

Mengawali kegiatan inti, pertama-tama peserta didik dihadapkan pada sesuatu yang menimbulkan kebingungan, kemudian dilanjutkan untuk tidak memberi generaliasi agar timbul keinginan untuk menyelidiki sendiri. Cara yang ditempuh adalah dengan mengajukan pernyataan dan pertanyaan-pertanyaan. Selanjutnya peserta didik diberikan kesempatan untuk mengidentifikasi sebanyak mungkin agenda masalah yang relevan dengan bahan pelajaran. Kemudian salah satunya dipilih dan dirumuskan dalam bentuk hipotesis. Ketika eksplorasi berlangsung, guru memberikan kesempatan kepada peserta didik untuk mengumpulkan informasi sebanyak-banyaknya yang relevan untuk membuktikan benar atau tidaknya hipotesis. Data dan informasi yang telah diperoleh peserta didik baik melalui membaca, mengamati dan cara lainnya dari berbagai media baik cetak atau elektronik, ditafsirkan/dibahas oleh peserta didik dalam kelompoknya untuk dapat menjawab permasalahan yang telah ditetapkan 
sebelumnya. Kemudian pada akhirnya peserta didik diarahkan untuk menyimpulkan berbagai konsep atau pengetahuan terutama yang berhubungan dengan materi pelajaran.

Aktivitas guru dan peserta didik dalam KBM dengan model discovery learning pada tatap muka ke 1 dari hasil observasi diperoleh nilai rata rata 80 (untuk ativitas guru) dan 40 (untuk aktivitas peserta didik).

Tatap muka ke dua dilaksanakan pada hari senin tanggal 12 Mei 2018 jam pelajaran ke $3-4$ pukul $10.00-11.30$ WIB. Pada pertemuan ini peserta didik mengikuti tes kompetensi menceritakan sejarah pertumbuhan ilmu pengetahuan Islam pada masa Nabi Muhammad SAW, masa Khulafaur Rasyidin, masa Bani Umayyah dan masa Bani Abbasiyah dan diminta untuk mengisi angket motivasi belajar yang telah disiapkan. Tujuannya adalah untuk mengukur sejauhmana tingkat motivasi belajar peserta didik dalam mengikuti pembelajaran. Dari hasil rekapitulasi skor angket motivasi belajar peserta didik, diperoleh nilai rata rata 77.

Evaluasi dilakukan untuk melihat efektifitas pembelajaran sejarah perkembangan ilmu pengetahuan Islam dengan model discovery learning terhadap peningkatan motivasi dan hasil belajar peserta didik. Efektifitas proses pembelajaran dilihat dari aktivitas guru dan peserta didik selama proses pembelajaran sedangkan motivasi dan hasil belajar peserta didik dilihat dari hasil angket dan tes peserta didik secara individu.

Evaluasi proses pembelajaran pada penelitian tindakan siklus I dilakukan melalui pengamatan terhadap proses pembelajaran pertemuan ke 1 . Hasil evaluasi proses pembelajaran siklus I tergambar dalam grafik di bawah ini:

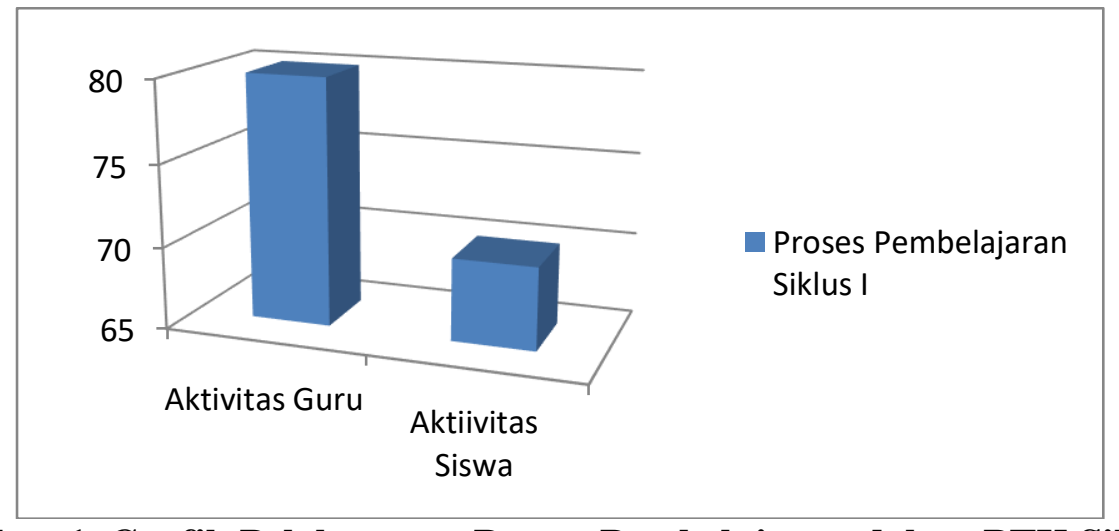

\section{Gambar 1. Grafik Pelaksanaan Proses Pembelajaran dalam PTK Siklus I}

Untuk lebih detilnya saya tampilkan tabel aktivitas guru dan peserta didik pada tabel berikut ini :

Tabel 1. Aktivitas Guru dan Peserta didik Siklus I

\begin{tabular}{|c|l|c|c|l|c|}
\hline No. & \multicolumn{1}{|c|}{ Aktivitas Guru } & Skor & No & \multicolumn{1}{|c|}{ Aktivitas Peserta didik } & Skor \\
\hline 1 & $\begin{array}{l}\text { Memberikan motivasi kepada } \\
\text { peserta didik }\end{array}$ & 5 & 1 & $\begin{array}{l}\text { Peserta didik siap untuk } \\
\text { mengikuti proses pembelajaran. }\end{array}$ & 4 \\
\hline 2 & $\begin{array}{l}\text { Menyampaikan tujuan } \\
\text { pembelajaran dan system } \\
\text { penilaian. }\end{array}$ & 5 & 2 & $\begin{array}{l}\text { Peserta didik memiliki motivasi } \\
\text { untuk terus belajar. }\end{array}$ & 4 \\
\hline 3 & $\begin{array}{l}\text { Memberikan penjelasan kepada } \\
\text { peserta didik bagaimana cara } \\
\text { membentuk kelompok yang } \\
\text { efektif dan bagaimana cara } \\
\text { bekerja sama dalam kelompok. }\end{array}$ & 5 & 3 & $\begin{array}{l}\text { Peserta didik disiplin melakukan } \\
\text { semua intruksi guru. }\end{array}$ & 4 \\
\hline 4 & $\begin{array}{l}\text { Memberikan bimbingan dan } \\
\text { arahan kepada semua } \\
\text { kelompok pada saat } \\
\text { mengerjakan tugas. }\end{array}$ & 4 & 4 & $\begin{array}{l}\text { Peserta didik mampu memusatkan } \\
\text { perhatian. }\end{array}$ & 3 \\
\hline
\end{tabular}




\begin{tabular}{|c|l|c||c|l|c|}
\hline 5 & $\begin{array}{l}\text { Memberikan } \\
\text { stimulasi/rangsangan dengan } \\
\text { memberikan persoalan yang } \\
\text { berhubungan dengan materi } \\
\text { pelajaran. }\end{array}$ & 3 & 5 & $\begin{array}{l}\text { Peserta didik memperhatikan } \\
\text { dengan seksama. }\end{array}$ & 3 \\
\hline 6 & $\begin{array}{l}\text { Memberikan kesempatan } \\
\text { kepada peserta didik untuk } \\
\text { mengidentifikasi sebanyak } \\
\text { mungkin agenda masalah yang } \\
\text { relevan dengan materi } \\
\text { pelajaran kemudian salah } \\
\text { satunya dipilih dan dirumuskan } \\
\text { dalam bentuk hipotesis. }\end{array}$ & 3 & 6 & $\begin{array}{l}\text { Peserta didik mengajukan } \\
\text { pertanyaan-pertanyaan untuk } \\
\text { dirumuskan dalam bentuk } \\
\text { hipotesis. }\end{array}$ & 3 \\
\hline 7 & $\begin{array}{l}\text { Memberikan kesempatan } \\
\text { kepada peserta didik untuk } \\
\text { mengumpulkan informasi } \\
\text { sebanyak-banyaknya yang } \\
\text { relevan untuk membuktikan } \\
\text { hipotesis benar/salah. }\end{array}$ & 3 & 7 & $\begin{array}{l}\text { Peserta didik aktif mengumpulkan } \\
\text { informasi dari berbagai media } \\
\text { (cetak dan elektronik) dalam } \\
\text { kelompok. }\end{array}$ & 2 \\
\hline 8 & $\begin{array}{l}\text { Membimbing peserta didik } \\
\text { dalam mengolah data dan } \\
\text { informasi yang telah diperoleh. }\end{array}$ & 4 & 8 & $\begin{array}{l}\text { Peserta didik aktif mengemukakan } \\
\text { informasi yang telah } \\
\text { diperolehnya. }\end{array}$ & 5 \\
\hline 9 & $\begin{array}{l}\text { Memberikan kesempatan } \\
\text { kepada peserta didik untuk } \\
\text { menemukan konsep, aturan } \\
\text { atau pemahaman melalui } \\
\text { contoh yang dijumpai dalam } \\
\text { kehidupan. }\end{array}$ & 4 & 9 & $\begin{array}{l}\text { Peserta didik aktif berdiskusi } \\
\text { dalam kelompok untuk } \\
\text { menemukan pemahaman melalaui } \\
\text { contoh yang dijumpai dalam } \\
\text { kehidupan. }\end{array}$ & 4 \\
\hline 10 & $\begin{array}{l}\text { Membimbing peserta didik } \\
\text { untuk menarik kesimpulan } \\
\text { dengan kata-kata tentang } \\
\text { prinsip-prinsip umum } \\
\text { berdasarkan hasil verifikasi } \\
\text { pada tahap sebelumnya. }\end{array}$ & 4 & 10 & $\begin{array}{l}\text { Peserta didik aktif dan } \\
\text { komunikatif. }\end{array}$ & 3 \\
\hline Jumlah Skor & & $\mathbf{4 0}$ & Jumlah Skor & $\mathbf{3 5}$ \\
\hline Rerata \% & Rerata \%o & \\
\hline
\end{tabular}

Grafik dan tabel di atas menjelaskan kepada kita bahwa pembelajaran PAI dengan materi sejarah perkembangan ilmu pengetahuan Islam dengan model discovery learning dapat dilaksanakan dengan baik oleh guru dan peserta didik. Hal ini terbukti dengan diperolehnya skor aktivitas guru sebesar 80 dan skor aktivitas peserta didik sebesar 70 berada pada kategori baik. Namun jika kita amati lebih cermat, dari 10 komponen yang diamati ternyata ada beberapa kegiatan yang belum dilaksanakan secara optimal, yaitu komponen no. 4, 5, 6, 7, dan 10.

Penilaian motivasi belajar peserta didik dilaksanakan dengan pengisian angket/kuesioner oleh peserta didik pada pertemuan ke 2. Berikut ini peneliti sajikan grafik perkembangan motivasi belajar peserta didik kelas VIII B SMP N 1 Tasikmalaya sebelum dan sesudah dilakukan PTK siklus I: 


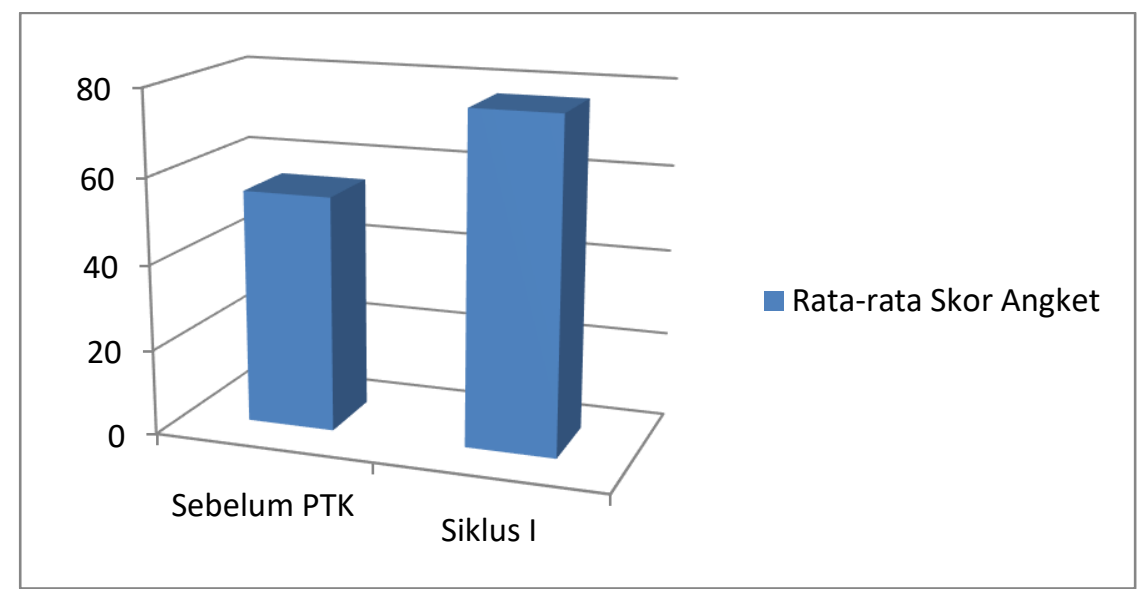

\section{Gambar 2. Grafik Perkembangan Motivasi Belajar Siswa sebelum dan Sesudah PTK Siklus I}

Grafik di atas menjelaskan kepada kita bahwa ada kenaikan tingkat motivasi belajar peserta didik sebelum dan setelah diadakan PTK siklus I meskipun kenaikan tersebut belum signifikan. Dari evaluasi hasil angket motivasi belajar peserta didik juga ditemukan beberapa indikator motivasi yang masih rendah, yaitu indikator no. 9, 10, 19, dan 20. Hal ini dapat dilihat pada grafik rekapitulasi nilai angket motivasi belajar peserta didik sebagai berikut:

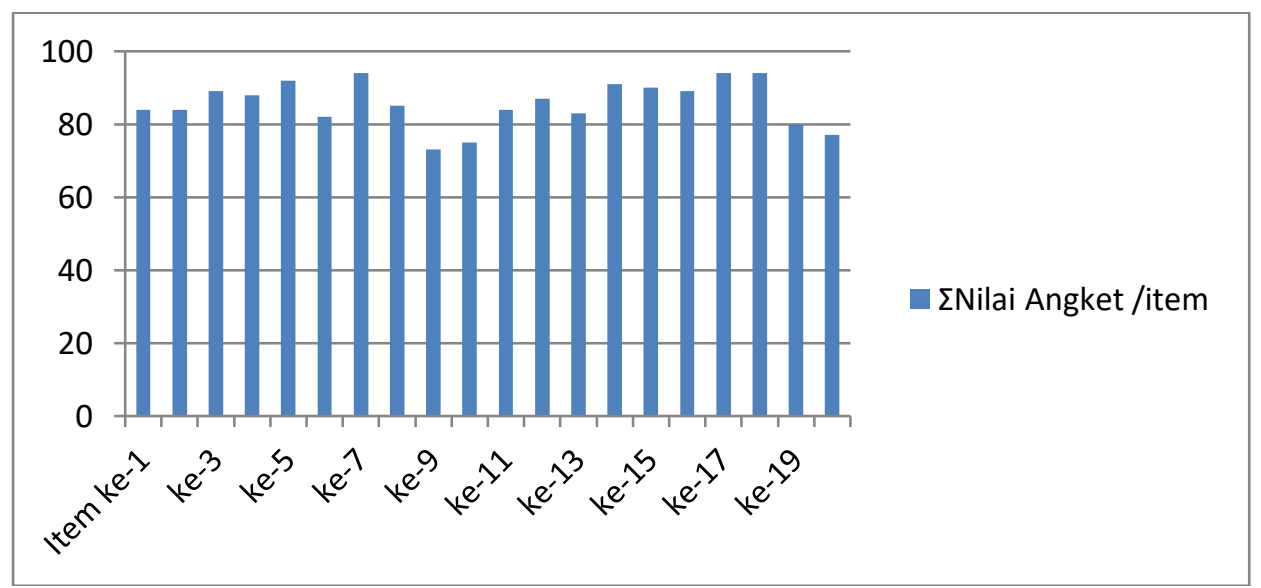

\section{Gambar 3. Grafik Rekapitulasi Nilai Angket Motivasi Belajar Peserta didik Siklus I}

Indikator motivasi belajar no. 9, 10, 19, dan 20 adalah tentang motivasi untuk lebih aktif mencari sumber materi pembelajaran PAI, untuk bekerjasama dalam kelompok, untuk lebih berani dalam mengungkapkan pendapat, dan motivasi untuk lebih aktif dalam mengungkapkan pendapat.

Dari hasil evaluasi pembelajaran siklus I yang meliputi evaluasi proses pembelajaran, evaluasi motivasi belajar peserta didik, dan evaluasi hasil belajar peserta didik, terdapat beberapa permasalahan yang harus ditemukan solusinya. Di antara permasalahan tersebut adalah para peserta didik masih kurang dalam perhatian, kurang aktif mengajukan pertanyaanpertanyaan untuk dirumuskan dalam bentuk hipotesis, kurang aktif dalam mengumpulkan informasi dari berbagai media (cetak dan elektronik) serta kurang aktif dan komunikatif dalam mengkomunikasikan hasil diskusinya. Dalam motivasi belajar, para peserta didik masih kurang terutama dalam motivasi untuk lebih aktif mencari sumber materi pembelajaran PAI, untuk bekerjasama dalam kelompok. untuk lebih berani dalam mengungkapkan pendapat, dan motivasi untuk lebih aktif dalam mengungkapkan pendapat.

Permasalahan-permasalahan tersebut didiskusikan antara peneliti dengan observer untuk mencari cara mengatasinya. Hasil diskusi akan dijadikan bahan untuk perbaikan bagi peneliti dalam merancang dan melaksanakan proses pembelajaran siklus II. Berikut ini 


\section{EDUCATOR : Jurnal Inovasi Tenaga Pendidik dan Kependidikan Vol. 1 No. 2 Desember 2021, e-ISSN : 2807-8659 | p-ISSN : 2807-8829}

beberapa hal hasil diskusi untuk perbaikan pada siklus II, yaitu: a) Desain pembelajaran harus disempurnakan terutama dalam kegiatan inti Stimulation (stimulasi/pemberian rangsangan) sehingga para peserta didik lebih termotivasi untuk mengikuti pembelajaran. b) Memberikan kesempatan lebih luas kepada para peserta didik untuk mengajukan pertanyaan sesuai dengan materi rangsangan yang telah diberikan. c) Meningkatkan intensitas bimbingan kepada tiap kelompok belajar agar kegiatan diskusi kelompoknya lebih terarah d) Memberikan kesempatan lebih luas kepada para peserta didik untuk bersama-sama menyimpulkan hasil pembelajaran. d) Memberikan tambahan stimulus berupa nilai bagi para peserta didik yang aktif dalam mengikuti setiap langkah dalam pembelajaran.

\section{Siklus II}

Pelaksanaan pembelajaran siklus II dengan model discovery learning membahas tentang sejarah pertumbuhan ilmu pengetahuan dalam Islam dengan kompetensi dasar menyebutkan tokoh ilmuwan Muslim dan perannya sampai masa daulah Abbasiyah.. Siklus II dilaksanakan dalam satu kali tatap muka pembelajaran dan satu kali tatap muka untuk ulangan harian.

Tatap muka pertama dilaksanakan pada hari senin tanggal 19 Mei 2018 jam pelajaran ke $3-4$ pukul 10.00 - 11.30 WIB. Setelah mengucapkan salam dan tegur sapa, guru mengecek kehadiran peserta didik, kemudian memotivasi peserta didik mengenai pentingnya mengetahui tokoh-tokoh cendikiawan muslim dunia. Selanjutnya peserta didik menjawab pertanyaan apersepsi dan menyimak tujuan pembelajaran yang harus dicapai pada pertemuan tersebut dan system penilaiannya serta menerima penjelasan tentang model discovery learning.

Mengawali kegiatan inti, pertama-tama peserta didik dihadapkan pada sesuatu yang menimbulkan kebingungan, kemudian dilanjutkan untuk tidak memberi generaliasi agar timbul keinginan untuk menyelidiki sendiri. Pada tahap ini guru memberikan persoalan atau peserta didik membaca atau mendengarkan uraian permasalahan. Cara yang ditempuh adalah dengan mengajukan pernyataan dan pertanyaan-pertanyaan. Selanjutnya peserta didik diberikan kesempatan untuk mengidentifikasi sebanyak mungkin agenda masalah yang relevan dengan bahan pelajaran. Kemudian salah satunya dipilih dan dirumuskan dalam bentuk hipotesis. Ketika eksplorasi berlangsung, guru memberikan kesempatan kepada peserta didik untuk mengumpulkan informasi sebanyak-banyaknya yang relevan untuk membuktikan benar atau tidaknya hipotesis. Data dan informasi yang telah diperoleh peserta didik baik melalui membaca, mengamati dan cara lainnya dari berbagai media baik cetak atau elektronik, ditafsirkan/dibahas oleh peserta didik dalam kelompoknya untuk dapat menjawab permasalahan yang telah ditetapkan sebelumnya. Kemudian pada akhirnya peserta didik diarahkan untuk menyimpulkan berbagai konsep atau pengetahuan terutama yang berhubungan dengan materi pelajaran.

Aktivitas guru dan peserta didik dalam KBM dengan model discovery learning pada tatap muka ke 1 dari hasil observasi diperoleh nilai rata rata 88 (untuk ativitas guru) dan 90 (untuk aktivitas peserta didik).

Tatap muka ke dua dilaksanakan pada hari senin tanggal 26 Mei 2018 jam pelajaran ke $3-4$ pukul $10.00-11.30$ WIB. Pada pertemuan ini peserta didik mengikuti tes kompetensi menyebutkan para ilmuwan Muslim dan peran mereka pada masa Bani Umayyah serta menyebutkan para ilmuwan Muslim dan peran mereka pada masa Bani Abbasiyah. Peserta didik juga diminta untuk mengisi angket motivasi belajar yang telah disiapkan. Tujuannya adalah untuk mengukur sejauhmana tingkat motivasi belajar peserta didik dalam mengikuti pembelajaran. Dari hasil rekafitulasi angket motivasi siswa diperoleh nilai rata rata 84 .

Evaluasi proses pembelajaran pada penelitian tindakan siklus II dilakukan melalui pengamatan terhadap proses pembelajaran pertemuan ke 1 . Hasil evaluasi proses pembelajaran siklus II tergambar dalam grafik di bawah ini: 


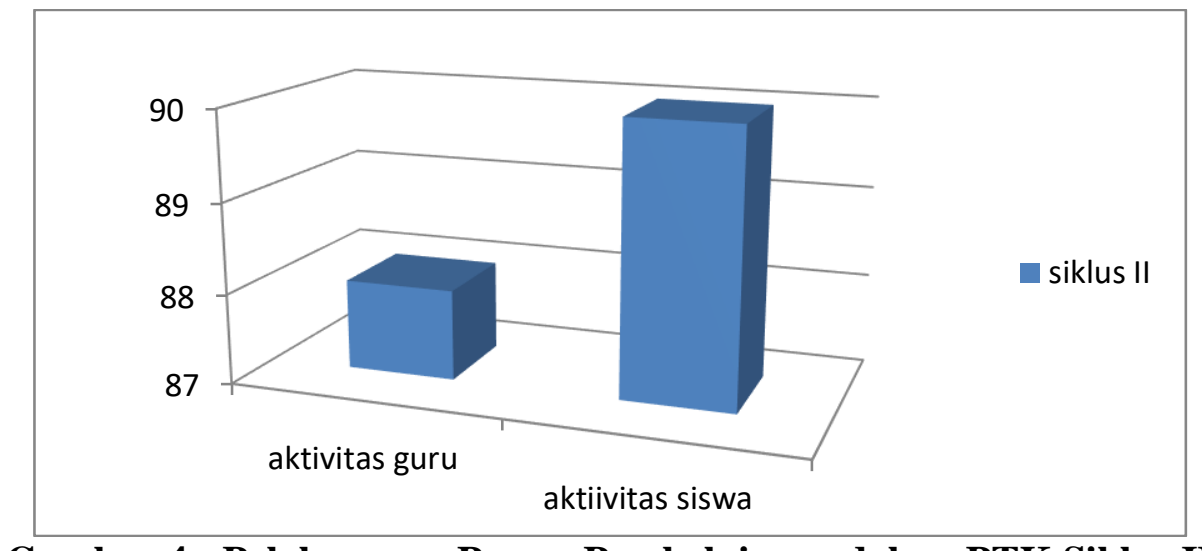

\section{Gambar 4 : Pelaksanaan Proses Pembelajaran dalam PTK Siklus II}

Grafik di atas menjelaskan kepada kita bahwa pembelajaran PAI dengan materi cendikiawan muslim dunia dengan model discovery learning dapat dilaksanakan dengan sangat baik oleh guru dan peserta didik. Hal ini terbukti dengan diperolehnya skor aktivitas guru sebesar 88 dan skor aktivitas peserta didik sebesar 90 berada pada kategori sangat baik.

Penilaian motivasi belajar peserta didik dilaksanakan dengan pengisian angket/kuesioner oleh peserta didik pada pertemuan ke 2 . Hasilnya dapat dilihat pada grafik berikut ini :

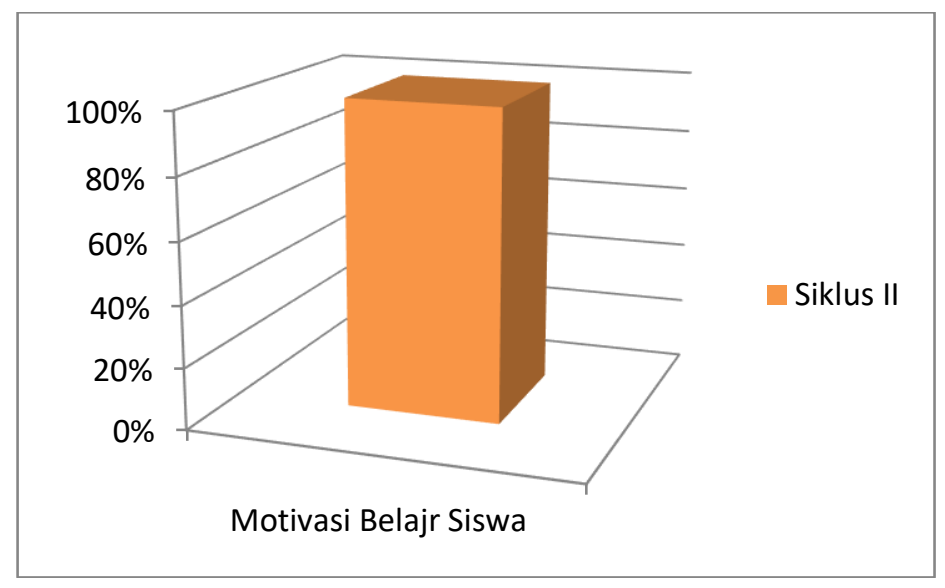

\section{Gambar 5. Grafik Motivasi Belajar Peserta didik dalam PTK Siklus II}

Evaluasi motivasi belajar peserta didik menunjukkan bahwa motivasi belajar peserta didik sangat tinggi. Hal ini terbukti dengan diperolehnya skor rerata sebesar 84 yang berada pada interval sangat tinggi. Dari evaluasi hasil angket motivasi belajar peserta didik juga menunjukkan semua indikator motivasi sudah merata pada tingkatan tinggi. Hal ini dapat dilihat pada grafik rekapitulasi nilai angket motivasi belajar peserta didik siklus II sebagai berikut:

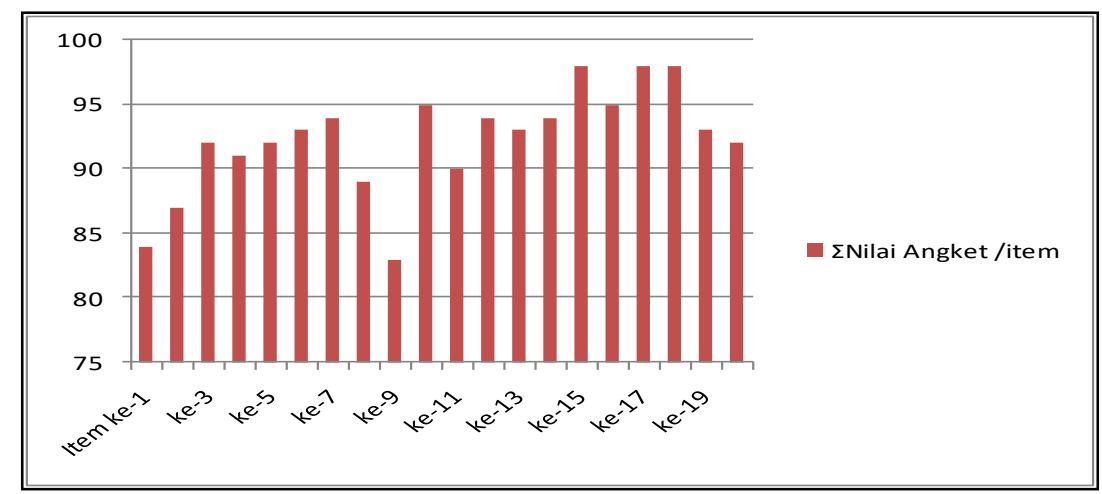

Gambar 6. Grafik Rekapitulasi Nilai Angket Motivasi Belajar Peserta didik dalam PTK Siklus II 


\section{Pembahasan}

Pelaksanaan pembelajaran dapat dilaksanakan dengan baik serta mengalami peningkatan pada setiap siklus. Dari hasil pengamatan observer, proses pembelajaran siklus I memperoleh skor 70 untuk aktivitas peserta didik dan 80 untuk aktivitas guru. Artinya aktivitas peserta didik dan guru dalam taraf sudah baik (aktif). Tetapi masih ada ketimpangan, yaitu adanya intensitas keaktivan peserta didik lebih rendah dari pada aktivitas guru. Idealnya adalah peserta didik yang lebih aktif dalam belajar, sedangkan peran guru hanya membimbing dan mengarahkan. Hal ini diperbaiki dalam proses pembelajaran pada siklus II. Dari hasil pengamatan observer, proses pembelajaran siklus II aktivitas peserta didik memperoleh skor 90 dan aktivitas guru 88. Artinya aktivitas peserta didik dan guru dalam taraf sangat baik (sangat aktif). Meskipun belum mencapai perbandingan yang ideal antara aktivitas peserta didik dan guru, tetapi pada dasarnya proses pembelajaran siklus II telah berhasil dilaksanakan dengan adanya kenaikan skor aktivitas guru dan peserta didik sebagai indikator keberhasilannya.

Motivasi belajar peserta didik selama mengikuti proses pembelajaran secara keseluruhan adalah baik dan mengalami peningkatan pada setiap siklus. Dari hasil pengukuran dengan angket motivasi, pada siklus I diperoleh skor rata-rata motivasi belajar peserta didik sebesar 77 (sangat bermotivasi). Dari hasil pengukuran tersebut, terdapat kelemahan yaitu ditemukannya beberapa indikator motivasi yang masih rendah, yaitu indikator no. 9, 10, 19, dan 20. Hal ini yang menjadi salah satu masukan untuk memperbaiki pada siklus II. Dari hasil pengukuran motivasi belajar peserta didik siklus II diperoleh skor rata-rata motivasi belajar peserta didik sebesar 84 . Artinya motivasi belajar peserta didik dalam taraf sangat tinggi. Selain itu skor motivasi belajar peserta didik per indikator/item relatif lebih merata. Hal ini sangat penting untk menunjang keberhasilan belajar peserta didik. Sebagaimana diungkapkan oleh Santrock (2004) bahwa motivasi adalah proses yang memberikan semangat, arah dan kegigihan perilaku. Artinya, perilaku yang termotivasi adalah perilaku yang penuh energy, terarah dan tahan lama. Motivasi merupakan aspek penting dari pengajaran dan pembelajaran. Siswa yang tidak punya motivasi tidak akan berusaha keras untuk belajar. Siswa yang bermotivasi tinggi senang ke sekolah dan menyerap proses belajar.

Hal ini senada dengan hasil peneltian yang telah dilakukan oleh Ramadhanti dkk. (2014) yang berhasil membuktikan bahwa pembelajaran dengan menggunakan strategi discovery leaning, suasana pembelajaran menjadi lebih aktif jika dibandingkan dengan tahap prasiklus. Selain itu juga siswa juga nampak lebih antusias dalam pembelajaran, terbukti saat melakukan percobaan, hampir semua siswa melakukannya. Suasana pembelajaran yang aktif membuat siswa senang dalam mengikuti pembelajaran. Sedangkan Nur Anisa dkk. (2017) telah mendeskripsikan kepraktisan, keefektifan dan ukuran pengaruh pembelajaran discovery learning dalam meningkatkan motivasi belajar dan penguasaan konsep siswa. Kesimpulan penelitiannya yaitu pembelajaran discovery learning memiliki pengaruh yang besar terhadap peningkatan motivasi belajar dan penguasaan konsep siswa.

Hasil dari evaluasi proses belajar peserta didik , motivasi belajar peserta didik siklus I dan siklus II disajikan dalam grafik sebagai berikut: 


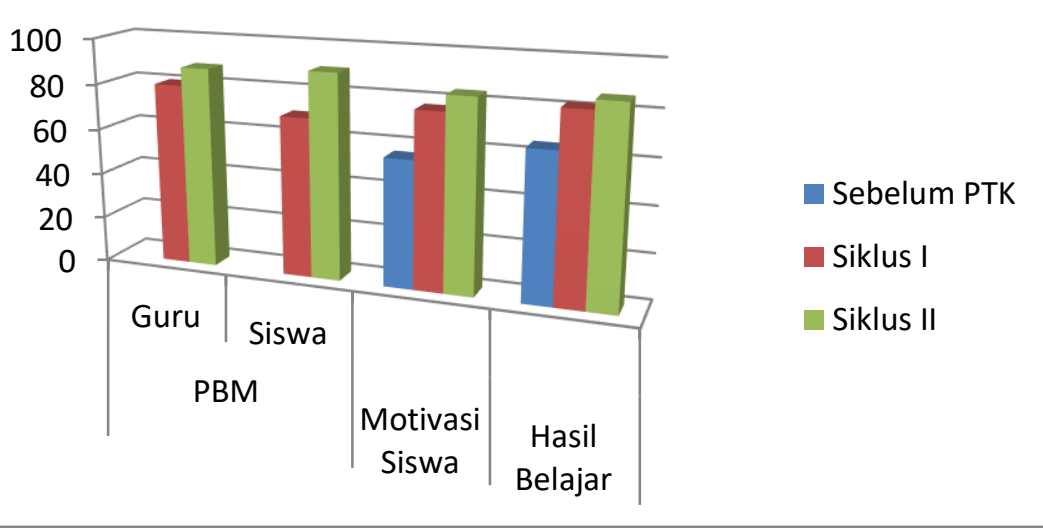

Gambar 7. Grafik Perkembangan PBM, Motivasi Belajar Peserta didik Pra PTK, Siklus I dan Siklus II

\section{KESIMPULAN}

Berdasarkan hasil analisi data dan pembahasan yang telah disajikan dapat disimpulkan bahwa penerapan model discovery learning dalam pembelajaran PAI pada pokok bahasan sejarah kebudayaan Islam dapat meningkatkan motivasi belajar peserta didik. Hal ini dibuktikan dengan meningkatnya rerata skor motivasi belajar peserta didik setiap siklus. Siklus I diperoleh skor rata-rata motivasi belajar peserta didik sebesar 77. Siklus II diperoleh skor ratarata motivasi belajar peserta didik sebesar 84. Penerapan model Discovery Learning cocok digunakan untuk materi sejarah karena mampu meningkatkan motivasi belajar peserta didik.

\section{DAFTAR PUSTAKA}

Arikunto, Suharsimi, at. al. (2007). Penelitian Tindakan Kelas. Bumi Aksara: Jakarta.

DEPAG RI. (2000). Al-Quran dan Terjemahnya. CV.Toha Putra: Semarang.

Nur Anisa, Ewid., Betta Rudibyani, Ratu., Sofya, Emmawaty. (2017). Pembelajaran Discovery Learning untuk Meningkatkan Motivasi Belajar dan Penguasaan Konsep Siswa. Jurnal Pendidikan dan pembelajaran Kimia.

Ramadhanti, Geby., Nuriman dan Khutobah. (2014). Penerapan Strategi Discovery untuk Meningkatkan Motivasi dan Hasil Belajar Siswa Kelas Vb Pokok Bahasan Pesawat Sederhana di SD Negeri Ajung 03. Artikel Ilmiah Mahasiswa. https://repository.unej.ac.id/bitstream/handle/123456789/63265/GEBY\%20RAMAD HANTI.pdf?sequence $=1$ \&isAllowed $=\mathrm{y}$

Sanjaya, H. Wina. (2014). Strategi Pembelajaran Berorientasi Standar Pendidikan. Prenada Media Group: Jakarta.

Sudijono, Anas. (2006). Pengantar Evaluasi Pendidikan. Rajawali Pers: Jakarta.

Sukardi. (2007). Metodologi Peneltian Pendidikan; Kompetensi dan Prakarya. Bumi Aksara: Jakarta.

Sugiyono. (2007). Metode Penelitian Pendidikan; Pendekatan Kuantitatif, Kualitatif, dan R \& $D$. Alfabeta: Bandung.

Santrock, John. W. (2004). Educational Psychologi. $2^{\text {nd }}$ Edition: McGraw-Hill Company, Inc.

Tafsir, Ahmad. (2004). Ilmu Pendidikan dalam Perspektif Islam. PT Remaja Rosdakarya: Bandung.

Team Penyusun. (2013). "Perencanaan Pembelajaran, Pendidikan dan Latihan Profesi Guru (PLPG). Rayon Fakultas Tarbiyah dan Keguruan UIN Bandung: Bandung.

W. Rochiati. (2009). Metode Penelitian Tindakan Kelas untuk Meninkatkan Kinerja Guru dan Dosen. Remaja Rosdakarya: Bandung.

Yamin, H. Martinis. (2008). Paradigma Pendidikan Konstruktivistik. Gaung Persada Pres: Jakarta. 